\title{
Folic acid deficiency in leukaemia and lymphomas
}

\author{
D. P. ROSE \\ From the University Department of Chemical Pathology, Royal Infirmary, Sheffield
}

SYNOPSIS Serum folic acid levels and the urinary excretion of Figlu have been studied in patients with leukaemia or lymphomas. The results indicate that folic acid deficiency is a common complication of these diseases. Bone marrow examinations of those with evidence of such a deficiency frequently show megaloblastic erythropoiesis.

The Figlu test appears to be a useful screening test for folic acid deficiency in patients with leukaemia or lymphomas.

Evidence that folic acid deficiency may develop in patients suffering from leukaemia or lymphomas has been obtained from studies of the excretion of folic acid in urine (Swendseid, Swanson, Meyers, and Bethell, 1952; Girdwood, 1953), of the rate of clearance of injected folic acid from the plasma (Hogan, Maniatis, and Moloney, 1964), and from serum folic acid assays (Hoogstraten, Baker, and Reizen-stein, 1961; Rao, Lagerlöf, Einhorn, and Reizen-stein, 1963; Kershaw and Girdwood, 1964).

The number of patients studied by previous authors has been too small to indicate the frequency with which folic acid deficiency is a complicating factor in the various forms of leukaemia and lymphomas. In the present study groups of patients with acuteleukaemia, chronic lymphocytic leukaemia, lymphosarcoma, reticulum cell sarcoma, and Hodgkin's disease have been investigated for evidence of folic acid deficiency. In addition to serum folic acid estimations and bone marrow examinations, the excretions of formiminoglutamic acid (Figlu) in urine have been estimated. Increased excretions of Figlu have been reported in malignant diseases (Dymock, 1964), but the significance of these observations remains to be established.

\section{MATERIAL AND METHODS}

The composition of the patients studied is given in Tables I (acute leukaemia) and II (chronic lymphocytic leukaemia and lymphomas). The cases of acute leukaemia were investigated before starting treatment.

The haematological estimations were performed by standard methods, the fasting serum folic acid assays by the Lactobacillus casei method (normal range 5 to 22 $\mathrm{m} \mu \mathrm{g}$. per $\mathrm{ml}$.), and the serum vitamin $\mathrm{B}_{12}$ assays by the Euglena gracilis technique (normal range 140 to $850 \mu \mu \mathrm{g}$. per $\mathrm{ml}$. .).

Received for publication 27 May 1965.
TABLE I

\begin{tabular}{clll} 
& \multicolumn{3}{c}{ PATIENTS WITH ACUTE LEUKAEMIA } \\
Case No. & Sex & Age & Diagnosis \\
\hline 1 & M & 15 & Myeloblastic leukaemia \\
2 & M & 53 & Myeloblastic leukaemia \\
3 & F & 64 & Myeloblastic lauekemia \\
4 & F & 19 & Myeloblastic leukaemia \\
5 & F & 76 & Myeloblastic leukaemia \\
6 & F & 41 & Myeloblastic leukaemia \\
7 & M & 52 & Acute stem cell leukaemia \\
8 & F & 78 & Subacute paramyeloblastic leukaemia \\
9 & F & 32 & Acute monomyelocytic leukaemia
\end{tabular}

Formiminoglutamic acid (Figlu) excretion in urine was estimated by the method of Kohn, Mollin, and Rosenbach (1961). A five-hour collection of urine was made commencing three hours after giving a $15 \mathrm{~g}$. oral dose of L-histidine, and the presence of Figlu was detected by cellulose acetate electrophoresis. The method is only semiquantitative and so the results have been grouped as follows:-Less than $2 \mathrm{mg}$. of Figlu excreted per hour $(0$, normal), 2 to $5 \mathrm{mg}$./hour $( \pm), 5$ to $10 \mathrm{mg}$./ hour $(+), 10$ to $20 \mathrm{mg}$./hour $(++), 20$ to $30 \mathrm{mg}$./hour $(+++)$, and more than $30 \mathrm{mg}$./hour $(++++)$.

\section{RESULTS}

aCUTE Leukaemia (NINE CASES) The results are given in Table III.

Six patients had reduced serum folic acid levels and four of these also had abnormal Figlu excretions. Two patients with normal serum folic acid results had raised outputs of Figlu. Megaloblasts or transitional megaloblasts were noted in the bone marrow smears of four cases, and the erythroblasts of another showed an abnormal degree of opening of the chromatin network which may have represented the earliest stage of megaloblastic change. Abnormal erythropoiesis was accompanied by a low serum folic acid level in all but one instance, and this 
TABLE II

PATIENTS WITH CHRONIC LYMPHOCYTIC LEUKAEMIA OR LYMPHOMAS

Case No. Sex Age Previous Therapy

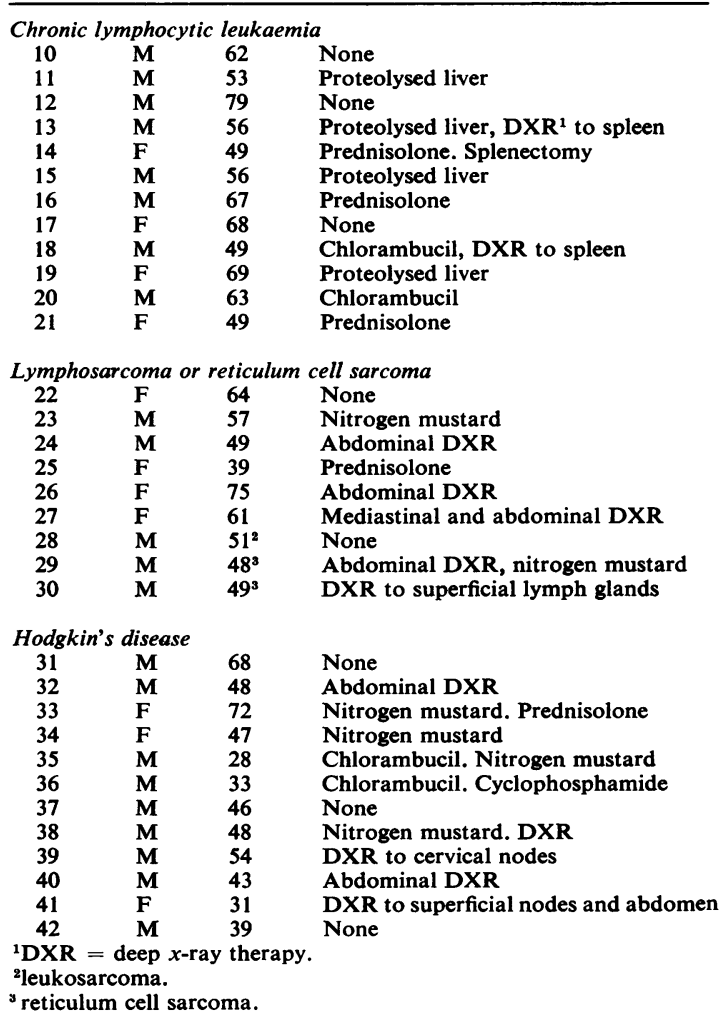

patient (case 4) excreted Figlu in increased quantity.

CHRONIC LYMPHOCYTIC LeUKAeMIA (12 CASES) The results are shown in Table IV.

Four patients had reduced serum folic acid levels and three of these tested also excreted an abnormal amount of Figlu in the urine. Two other patients also had increased outputs of Figlu. Bone marrow examinations were carried out, at the time of the other investigations, in three patients. Erythro poiesis was normoblastic, although in one cases (case 20) the serum folic acid level was reduced and the Figlu excretion was grossly abnormal.

LYMPHOSARCOMA AND RETICULUM CELL SARCOM (TABLE IV, NINE CASES) Six patients had low serum folic acid levels. Figlu excretions were estimated inf five of these and all gave abnormal results. Thre $\vec{e}$ patients with megaloblastic or transitional megalo blastic change in the bone marrow had evidence of folic acid deficiency.

HODGKIN's DISEASE (TABLE IV, 12 CASES) Seveño patients had both reduced serum folic acid levels and raised Figlu excretions. Two others had abnormado Figlu tests. The bone marrows of nine patients were examined and three showed transitional megalo= blastic erythropoiesis. These changes were accoms panied by low serum folic acid levels and increase $\Phi$ Figlu excretions.

RESPONSE TO FOLIC ACID THERAPY The response tem folic acid was studied in three patients with lymph omas.

Case 29 (reticulum cell sarcoma) showed a suddef fall in the haemoglobin level which was accompanieg by the appearance of macrocytes in the peripherat blood and megaloblasts in the bone marrowo Intestinal malabsorption was indicated by a faecal fat excretion of $8 \cdot 1 \mathrm{~g}$. per day (average result for $\bar{\Phi}$ four-day period; normal less than $6 \mathrm{~g}$. daily) and impaired xylose absorption ( $1 \cdot 3 \mathrm{~g}$. xylose excreted if five hours following a $25 \mathrm{~g}$. oral dose of xylose lower limit of the normal range $4.0 \mathrm{~g}$.). The serune folic acid level was low (1.5 $\mathrm{m} \mu \mathrm{g}$. per $\mathrm{ml}$.) and the Figlu test was abnormal $(+)$. Treatr.ent with folie acid, given orally in a dose of $15 \mathrm{mg}$. a day, produce $\$$ a rapid response with a maximum reticulocyte count of $14 \%$ followed by a rise in the haemoglobig level to $15.7 \mathrm{~g} . / 100 \mathrm{ml}$. The Figlu excretion was normal 12 days after starting folic acid therapy.

TABLE III

\begin{tabular}{|c|c|c|c|c|c|}
\hline Case No. & $\begin{array}{l}\text { Haemoglobin } \\
(\mathrm{g} . \text { per } 100 \mathrm{ml} .)\end{array}$ & $\begin{array}{l}\text { Total W.B.C. } \\
\text { (per c.mm.) }\end{array}$ & $\begin{array}{l}\text { Red Cell Precursors in Bone } \\
\text { Marrow }\end{array}$ & $\begin{array}{l}\text { Serum Folic Acid } \\
(m \mu g . \text { per } m l .)\end{array}$ & Figlu Excretion \\
\hline 1 & $6 \cdot 5$ & 30,000 & Transitional megaloblasts & $1 \cdot 4$ & + \\
\hline 3 & $9 \cdot 4$ & 2,000 & Megaloblasts & $4 \cdot 0$ & ++ \\
\hline 4 & 6.4 & 35,000 & Megaloblasts & 6.6 & ++ \\
\hline 5 & $5 \cdot 9$ & 7,000 & Normoblasts & $9 \cdot 6$ & 0 \\
\hline 6 & 6.9 & 28,000 & Normoblasts & $9 \cdot 8$ & + \\
\hline 8 & $8 \cdot 5$ & 77,000 & Transitional megaloblasts & $2 \cdot 8$ & +++ \\
\hline 9 & $7 \cdot 0$ & 12,000 & Normoblasts with open & $3 \cdot 7$ & 0 \\
\hline
\end{tabular}


TABLE IV

RESULTS IN CHRONIC LYMPHOCYTIC LEUKAEMIA AND LYMPHOMAS

\begin{tabular}{|c|c|c|c|c|c|c|}
\hline \multirow[t]{2}{*}{ Case No. } & \multirow{2}{*}{$\begin{array}{l}\text { Haemoglobin } \\
(g . \text { per } 100 \mathrm{ml} .)\end{array}$} & \multirow{2}{*}{$\begin{array}{l}\text { Total W.B.C.s } \\
\text { (per c.mm.) }\end{array}$} & \multirow{2}{*}{$\begin{array}{l}\text { Red Cell Precursors in Bone } \\
\text { Marrow }\end{array}$} & \multicolumn{2}{|l|}{ Serum } & \multirow[t]{2}{*}{ Figlu Excretion } \\
\hline & & & & $\begin{array}{l}\text { Vitamin } B_{12} \\
(\mu \mu g . / m l .)\end{array}$ & $\begin{array}{l}\text { Folic Acid } \\
(m \mu g . / m l .)\end{array}$ & \\
\hline \multicolumn{7}{|c|}{ Chronic lymphocytic leukaemia } \\
\hline 10 & $13 \cdot 0$ & 33,000 & - & - & $9 \cdot 6$ & 0 \\
\hline 11 & $10 \cdot 6$ & 410,000 & - & 424 & $10 \cdot 5$ & $\mathbf{0}$ \\
\hline 12 & $11 \cdot 1$ & 70,000 & Normoblasts & 598 & 7.6 & + \\
\hline 13 & $12 \cdot 1$ & 42,000 & - & 270 & $6 \cdot 1^{1}$ & 0 \\
\hline 14 & $10 \cdot 1$ & 36,000 & - & - & $2 \cdot 0$ & $++t$ \\
\hline 15 & $13 \cdot 2$ & 51,000 & Normoblasts & 226 & $13 \cdot 0^{1}$ & + \\
\hline 16 & 9.7 & 49,000 & - & 352 & 6.6 & 0 \\
\hline 17 & $8 \cdot 3$ & 210,000 & - & 488 & $4 \cdot 6$ & - \\
\hline 18 & $9 \cdot 0$ & 126,000 & - & 276 & $3 \cdot 8$ & ++ \\
\hline 19 & $7 \cdot 8$ & 700,000 & - & 920 & $9 \cdot 8^{1}$ & - \\
\hline 20 & $7 \cdot 7$ & 40,000 & Normoblasts & 172 & $3 \cdot 8$ & +++ \\
\hline 21 & 6.8 & 65,000 & - & 272 & $5 \cdot 9$ & 0 \\
\hline 23 & $12 \cdot 2$ & 2,500 & Transitional megaloblasts & 200 & $3 \cdot 8$ & +++ \\
\hline 24 & $10 \cdot 0$ & 18,000 & Some megaloblasts & 436 & $3 \cdot 5$ & \pm \\
\hline 25 & $11 \cdot 1$ & 57,000 & - & 262 & $3 \cdot 7$ & - \\
\hline 26 & $12 \cdot 2$ & 7,000 & Normoblasts & 284 & $2 \cdot 1$ & + \\
\hline 27 & $13 \cdot 2$ & 5,000 & Normoblasts & 320 & $8 \cdot 8$ & 0 \\
\hline 28 & $12 \cdot 3$ & 37,000 & Normoblasts & 362 & $9 \cdot 2$ & $\mathbf{0}$ \\
\hline 29 & $7 \cdot 6$ & 5,000 & Transitional megaloblasts & 266 & $1 \cdot 5$ & + \\
\hline 30 & $13 \cdot 2$ & 9,000 & — & 420 & 1.9 & ++ \\
\hline \multicolumn{7}{|c|}{ Hodgkin's disease } \\
\hline 31 & $9 \cdot 7$ & 6,000 & Normoblasts & 124 & $2 \cdot 8$ & $+t$ \\
\hline 32 & $10 \cdot 6$ & 5,000 & - & 554 & 6.9 & 0 \\
\hline 33 & $7 \cdot 8$ & 6,000 & Aplastic & 190 & $1 \cdot 5$ & + \\
\hline 34 & $11 \cdot 5$ & 8,000 & - & 134 & $6 \cdot 8$ & o \\
\hline 35 & $9 \cdot 7$ & 20,000 & - & 326 & $2 \cdot 1$ & $+t$ \\
\hline 36 & $7 \cdot 6$ & 1,700 & - & 286 & $4 \cdot 6$ & $+t+t$ \\
\hline 37 & $12 \cdot 2$ & 15,000 & Normoblasts & 394 & $7 \cdot 1$ & $++t$ \\
\hline 38 & $8 \cdot 8$ & 4,000 & Transitional megaloblasts & 530 & $2 \cdot 0$ & ++ \\
\hline 41 & $9 \cdot 2$ & 6,000 & Micronormoblasts & 340 & $5 \cdot 0$ & 0 \\
\hline 42 & $8 \cdot 6$ & 7,000 & Transitional megaloblasts & 454 & 1.6 & ++ \\
\hline
\end{tabular}

${ }^{1}$ Patients receiving proteolysed liver extract.

Case 40 (Hodgkin's disease) also presented with a rapidly developing megaloblastic anaemia. The results of the serum folic acid assay and the Figlu test were consistent with folic acid deficiency and he was treated with folic acid, $15 \mathrm{mg}$. daily. Within one month the haemoglobin level had risen from 6.0 to $10 \cdot 2 \mathrm{~g}$. per $100 \mathrm{ml}$. and three months later it was $15 \cdot 2 \mathrm{~g} . / \mathrm{ml}$. The Figlu excretion test became normal and the macrocytes disappeared from the peripheral blood.

Case 38 (Hodgkin's disease) had suffered from a microcytic anaemia, requiring blood transfusions, for several months. At the time of investigation, however, he had developed a severe glossitis and macrocytes were present in the peripheral blood. A bone marrow examination showed megaloblastic erythropoiesis and there was evidence of folic acid deficiency. The glossitis improved rapidly with folic acid therapy. There was, however, no improvement in the haemoglobin level, the haematological features being again those of a microcytic, normochromic anaemia.

\section{DISCUSSION}

The cause of folic acid deficiency in leukaemia and lymphomas has not been established with certainty. Leukaemia cells have a higher folic acid content than normal leucocytes (Swendseid, Bethell, and Bird, 1951) suggesting that one factor may be an abnormal demand for folic acid derivatives. Impaired intestinal absorption may also play a part in chronic lymphocytic leukaemia and lymphomas (Pitney, Joske, and Mackinnon, 1960, and case 29 in the present series).

Previous workers have reported low serum folic acid levels in leukaemias and lymphomas. Rao et al. (1963) estimated the fasting serum folic acid activity by the Lactobacillus casei method in nine cases of leukaemia or myelomatosis, considered as a single 
group, and found the mean of the results $(2.4 \mathrm{~m} \mu \mathrm{g}$. per ml.) to be significantly lower than the mean result for 16 control subjects $(5.0 \mathrm{~m} \mu \mathrm{g}$. per ml.). Kershaw and Girdwood (1964) obtained low serum folic acid results in four of 12 patients with various forms of leukaemia, although the Figlu excretions were normal. These authors also investigated six patients with lymphomas. Three had low serum folic acid levels and two of these excreted Figlu in increased amounts.

In the present study four patients with acute leukaemia and three with chronic lymphocytic leukaemia had low serum folic acid levels and abnormal Figlu outputs. Two other cases of acute leukaemia had low serum folic acid levels but normal Figlu tests. Twenty patients suffering from a form of lymphoma were also studied and in 13 the serum folic acid level was reduced. All 12 of the 13 who were tested also excreted increased amounts of Figlu in the urine.

The frequency with which megaloblastic or transitional megaloblastic erythropoiesis was observed is of some interest. Reisner (1958) has described what he regarded as true megaloblasts in acute leukaemia. Dacie and White (1949), however, used the term 'megaloblastiform' to describe erythroblasts with an open chromatin network and advanced haemoglobinization which they observed in this condition. Their view was that these cells were not true megaloblasts, but that they arose from the 'leukaemic stimulus' which produced a disordered erythropoiesis as well as the malignant proliferation of leucocytes. Chanarin, Bennett, and Berry (1962) studied six untreated patients with acute myeloblastic leukaemia, three of whom showed megaloblastic change in the bone marrow. Five, including the three with megaloblastic erythropoiesis, had normal excretions of Figlu and urocanic acid in the urine. The other patient excreted large amounts of urocanic acid, but only a trace of Figlu. Villamil and McCracken (1963) found abnormal Figlu excretions in two of five patients with acute myeloblastic leukaemia and megaloblasts in the bone marrow. In the present series four patients with acute leukaemia and six with lymphomas showed megaloblastic or transitional megaloblastic change. All but one of those with acute leukaemia and all of

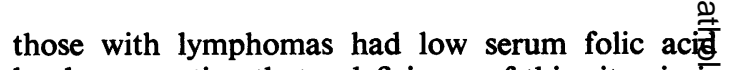
levels, suggesting that a deficiency of this vitamin is the usual cause of megaloblastic erythropoiesis these diseases.

The clinical significance of folic acid deficiency leukaemia and lymphomas remains to be elucidate The administration of folic acid to patients wi acute leukaemia may accelerate the progress of the disease (Farber, Diamond, Mercer, Sylvester, and Wolff, 1948). The responses of the three patients wi lymphomas (cases 29, 38, and 40 in the present series) suggest that folic acid therapy may have place in the management of these diseases when the is evidence of folate deficiency.

The results of the Figlu tests agreed well, on the whole, with the serum folic acid levels. There wer $\overrightarrow{\text {, }}$ however, six patients with increased Figlu excretiofs but normal serum folic acid results. These may hate resulted from malignant infiltration of the livet with impairment of the enzymes concerned histidine metabolism. One of the six patients (case 37) had abnormal liver function tests.

I am grateful to Dr. E. K. Blackburn for his encouragor ment, the results of the haematological investigations and for access to his patients. I also wish to thank Dr. A. Jordan, in whose department this work was carried out for his help and advice.

REFERENCES

Chanarin, I., Bennett, M. C., and Berry, V. (1962). J. clin. Path., 269.

Dacie, J. V., and White, J. C., (1949). Ibid., 2, 1.

Dymock, I. W. (1964). Lancet, 2, 114.

Farber, S., Diamond, L. K., Mercer, R. D., Sylvester, R. F. Jr., a⿳亠口冋g Wolff, J. A. (1948). New Engl. J. Med., 238, 787.

Girdwood, R. H. (1953). Brit. med. J., 2, 741.

Hogan, J. A., Maniatis, A., and Moloney, W. C. (1964). Blood, 24, 18. Hoogstraten, B., Baker, H., and Reizenstein, P. (1961). Ibid., 18, 783. Kershaw, P. W., and Girdwocd, R. H. (1964). Scot. med. J., 9, 20 D
Kohn, J., Mollin, D. L., and Rosenbach, L. M. (1961). J. clin. Pat $14,345$.

Pitney, W. R., Joske, R. A., and Mackinnon, N. L. (1960). Ibid., 吕,

Rao, P. B. R., Lagerlöf, B., Einhorn, J., and Reizenstein, P. (196‡). Lancet, 1, 1192.

Reisner, E. H. Jr. (1958). Blood, 13, 313.

Swendseid, M. E., Bethell, F. H., and Bird, O. D. (1951). Cancer Rê.,

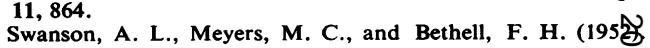
Blood, 7, 307.

Villamil, A., and McCracken, B. H. (1963). Brit. med.J., 1, 717. 